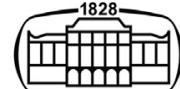

AKADÉMIAI KIADÓ

\title{
Determination of narciclasine in mouse blood by UPLC-MS/MS and its application to a pharmacokinetic study
}

\section{Acta Chromatographica}

34 (2022) 2, 115-119

\section{DOI:}

$10.1556 / 1326.2021 .00865$ (c) 2021 The Author(s)

\section{ORIGINAL RESEARCH} PAPER

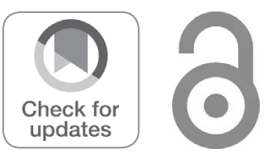

KE REN $^{1 \dagger}$, TIANTIAN FENG $^{2 \dagger}$, HAI SHI $^{1}$, JIANSHE MA $^{2 *}(\mathbb{0}$ and
YONGXI JIN $^{3 *}$ (D)

${ }^{1}$ Department of Pharmacy, Ningbo YinZhou No.2 Hospital, Ningbo, China

${ }^{2}$ School of Basic Medicine, Wenzhou Medical University, Wenzhou, China

${ }^{3}$ Department of Rehabilitation, Wenzhou Municipal Hospital of Traditional Chinese Medicine, Wenzhou, China

Received: October 12, 2020 • Accepted: January 29, 2021

Published online: February 25, 2021

\section{ABSTRACT}

Narciclasine is a 7-hydroxy derivative of lycorisidine. It was the first alkaloid isolated from the stem of narcissus (Amaryllidaceae) in 1967. Six mice were given narciclasine $(5 \mathrm{mg} / \mathrm{kg})$ by intravenous administration. A UPLC-MS/MS method was developed to determine narciclasine in mouse blood. Tectorigenin (internal standard, IS) and narciclasine were gradient eluted by mobile phase of methanol and $0.1 \%$ formic acid in a $\mathrm{BEH} \mathrm{C} 18$ column. The multiple reaction monitoring (MRM) of $\mathrm{m} / \mathrm{z}$ $308.1 \rightarrow 248.1$ for narciclasine and $m / z 301.1 \rightarrow 286.0$ for IS with an electrospray ionization (ESI) source was used for quantitative determination. The calibration curve ranged from 1 to $6,000 \mathrm{ng} / \mathrm{mL}$. The accuracy was from 92.5 to $107.3 \%$, and the matrix effect was between 103.6 and $107.4 \%$. The developed UPLC-MS/MS method was successfully applicated to a pharmacokinetic study of narciclasine in mice after intravenous administration $(5 \mathrm{mg} / \mathrm{kg})$.

\section{KEYWORDS}

narciclasine, mice, UPLC-MS/MS, determination, bioavailability

\section{INTRODUCTION}

In the history of human search for effective drugs, natural products have played a vital role. Especially in the field of cancer, more than $60 \%$ of drugs are derived from natural products. Plants in the Amaryllidaceae family are known for their medicinal effects and toxicity [1-4]. The role has been known for a long time. As far back as ancient Greece, narcissus extracts have been successfully used in cancer treatment. The 48 alkaloids isolated from narcissus have a carbon skeleton, but one group of these alkaloids is represented by the structure of hydroxybenzophenanthridone or isoquinolinone $[5,6]$. The most representative compounds are narciclasine, lycoricidine, and pancratistatin. The most commonly used term to define this group of alkaloids in the literature is called isoquinolone [7]. The cytotoxicity of these isoquinolone alkaloids has been confirmed in basic experiments as early as 30 years ago, and was later confirmed by NCI (International Cancer Agency) at the level of MTT colorimetric determination of human cancer cell lines $[8,9]$.

Narciclasine, lycorisidine (7-deoxynarcissus), squalene and its derivatives have shown effective anti-tumor cell line effects in vitro cytotoxicity experiments and in vivo experiments against mice M-5076 sarcoma and P-388 tumor activity [10, 11]. Therefore, this type of alkaloid with a new main structure is a new resource with potential and development as a future anti-cancer drug. Narciclasine does not affect the activity of proteases in vitro, but inhibits the synthesis of proteases at the ribosome level. Narciclasine is described as an 
anti-mitotic substance similar to colchicine. Narciclasine is also an inhibitor of peptide bond formation in eukaryotic ribosomes [12, 13]. It inhibits the formation of peptide bonds by combining with $60 \mathrm{~S}$ ribosomal subunits and peptidyl transferase centers. Unlike other anti-cancer drugs, narcissus does not interact with DNA to affect or form complexes.

To better understand the pharmacokinetics $[14,15]$, an analytical method for the determination of narciclasine in biological fluids is necessary. Svagrova et al. developed a reversed-phase high-performance liquid chromatography for determination of narciclasine in serum, with the retention time of narciclasine was $5 \mathrm{~min}$, and needed $0.5 \mathrm{~mL}$ blood for the sample preparation [16]. Until now, there were no reports about the pharmacokinetics of narciclasine in biological fluids by UPLC-MS/MS. Therefore, it was to develop a UPLC-MS/MS method for determination of narciclasine in mouse blood and used for pharmacokinetics.

\section{EXPERIMENTAL}

\section{Chemicals}

Narciclasine and tectorigenin (IS) (both purity >98\%) were from Chengdu Munster biotechnology Co. Ltd. (Chengdu, China). Milli-Q water system was from Millipore Sigma (Burlington, MA, USA). HPLC grade acetonitrile, formic acid and methanol were from Merck Company (Darmstadt, Germany).

\section{Instrument and condition}

An ACQUITY H-Class UPLC equipped with a XEVO TQSmicro triple quadrupole mass spectrometry (Waters Corp, Milford, MA, USA) with electrospray ionization (ESI), was used for analysis.

UPLC BEH C18 $(1.7 \mu \mathrm{m}, 2.1 \mathrm{~mm} \times 50 \mathrm{~mm})$ column was used for separation at $30{ }^{\circ} \mathrm{C}$. The mobile phase consisted of methanol and water $(0.1 \%$ formic acid $)$ with the flow rate of $0.4 \mathrm{~mL} / \mathrm{min}$. The gradient conditions with as follows: $0-0.2$ min, $10 \%$ methanol; $0.2-1.4 \mathrm{~min}, 10-85 \%$ methanol; $1.4-2.4$ min, $85 \%$ methanol; $2.4-2.5 \mathrm{~min}, 85-10 \%$, methanol; $2.5-4.5$ min, $10 \%$ methanol.

Capillary voltage was $2 \mathrm{kV}$, the temperature of source ionization was $150{ }^{\circ} \mathrm{C}$, dry gas (nitrogen) was $900 \mathrm{~L} / \mathrm{h}$, and the temperature for drying gas was $450{ }^{\circ} \mathrm{C}$. The $\mathrm{m} / z$ $308.1 \rightarrow 248.1$ for narciclasine (cone voltage $12 \mathrm{v}$, collision voltage $18 \mathrm{v}$ ) and $\mathrm{m} / \mathrm{z} 301.1 \rightarrow 286.0$ for IS (cone voltage $52 \mathrm{v}$, collision voltage $26 \mathrm{v}$ ), was used for quantitative analysis, in an ESI positive mode and MRM, Fig. 1.

\section{Calibration standards}

The stored solutions of narciclasine $(1.0 \mathrm{mg} / \mathrm{mL})$ and tectorigenin $(1.0 \mathrm{mg} / \mathrm{mL})$ were prepared in methanol. Working standard solutions were diluted by methanol, including 10 , $50,200,1,000,5,000,15,000,30,000,60,000 \mathrm{ng} / \mathrm{mL}$ for narciclasine. The working standard solution $(100 \mathrm{ng} / \mathrm{mL})$ of tectorigenin was diluted with methanol from the stored solution.

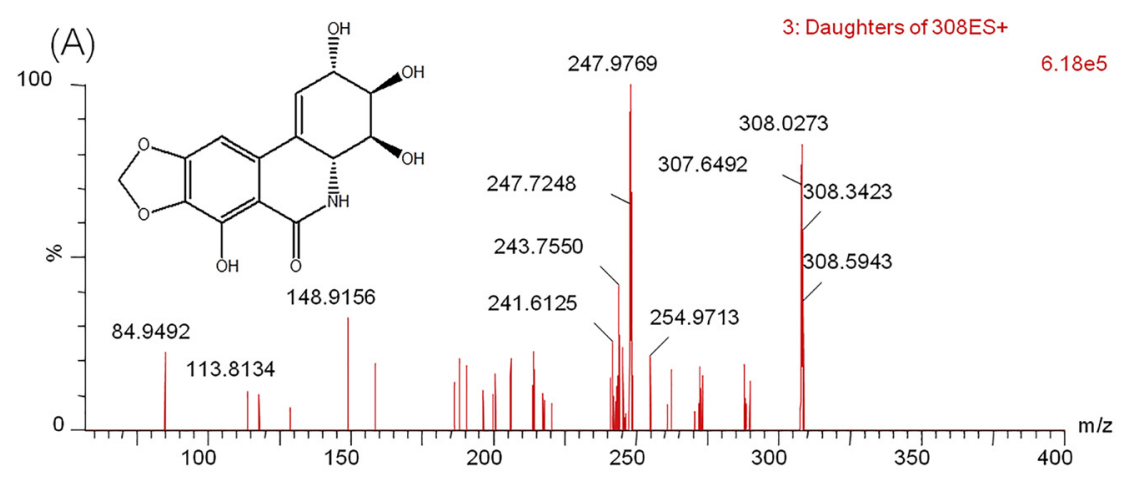

(B)

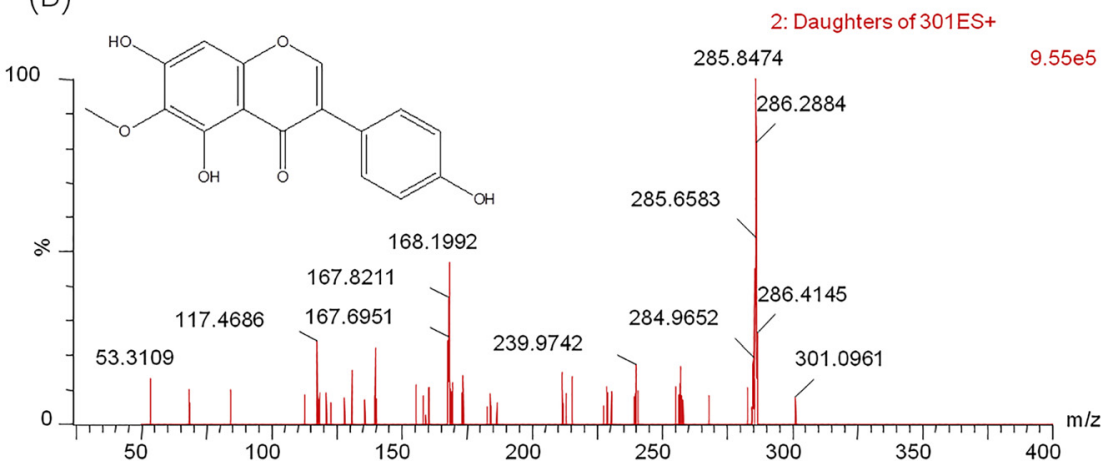

Fig. 1. Chemical structure and mass spectrum of narciclasine and tectorigenin (IS) 
Calibration standards of narciclasine were spiked to blank mouse blood to concentration of $1,5,20,100,500$, $1,500,3,000,6,000 \mathrm{ng} / \mathrm{mL}$. Three quality control (QC) samples were 2, 450 and 5,000 $\mathrm{ng} / \mathrm{mL}$.

\section{Sample preparation}

One hundred microliter acetonitrile (containing IS $100 \mathrm{ng} / \mathrm{mL}$ ) was added into $20 \mu \mathrm{L}$ blood, mixed for $1.0 \mathrm{~min}$, and centrifuged at $13,000 \mathrm{rpm}$ for $10 \mathrm{~min}$. The supernate $(2 \mu \mathrm{L})$ was injected into UPLC-MS/MS for analysis.

\section{Pharmacokinetic study}

Six Institute of Cancer Research (ICR) mice (male, 20-22 g) were from Laboratory Animal Center of Wenzhou Medical University (Wenzhou, China). The blood samples $(20 \mu \mathrm{L})$ were withdrawn from caudal vein after intravenous administration of narciclasine $(1 \mathrm{mg} / \mathrm{kg})$ at $0.083,0.5,1,1.5$, $2,3,4,6,8,12 \mathrm{~h}$, and stored at $-20^{\circ} \mathrm{C}$ until analysis. The data was fitted by the DSA 2.0 (China Pharmaceutical University, China).

\section{RESULTS}

\section{Method validation}

Fig. 2 exhibited the UPLC-MS/MS of a blank blood sample, a blank blood sample spiked with narciclasine and IS, and a blood sample obtained after intravenous administration. No interference was found at the retention times of the narciclasine and the IS.

The equation of the calibration curve $(1-6,000 \mathrm{ng} / \mathrm{mL})$ of narciclasine was: $y=0.0012 x+0.0012(r=0.9994, n=6)$, $y$ represented the ratio of the peak area of narciclasine to that of IS, and $x$ was the concentration of narciclasine. The LLOQ was $1 \mathrm{ng} / \mathrm{mL}$, the precision and accuracy of the LLOQ were 13.6 and $107.3 \%$, respectively.

The accuracy ranged from 92.5 to $107.3 \%$, the precision was less than $14 \%$, and the matrix effect was between $103.6 \%$ and $107.4 \%$, the recovery was better than $65.7 \%$, in Table 1 .

The stability of narciclasine in variations condition (3 freezing and thawing cycles, $-20{ }^{\circ} \mathrm{C}$ for 30 days, room temperature for $2 \mathrm{~h}$ ) was acceptable, the accuracy was within $86 \%$ and $114 \%$, and precision was less than $14 \%$.
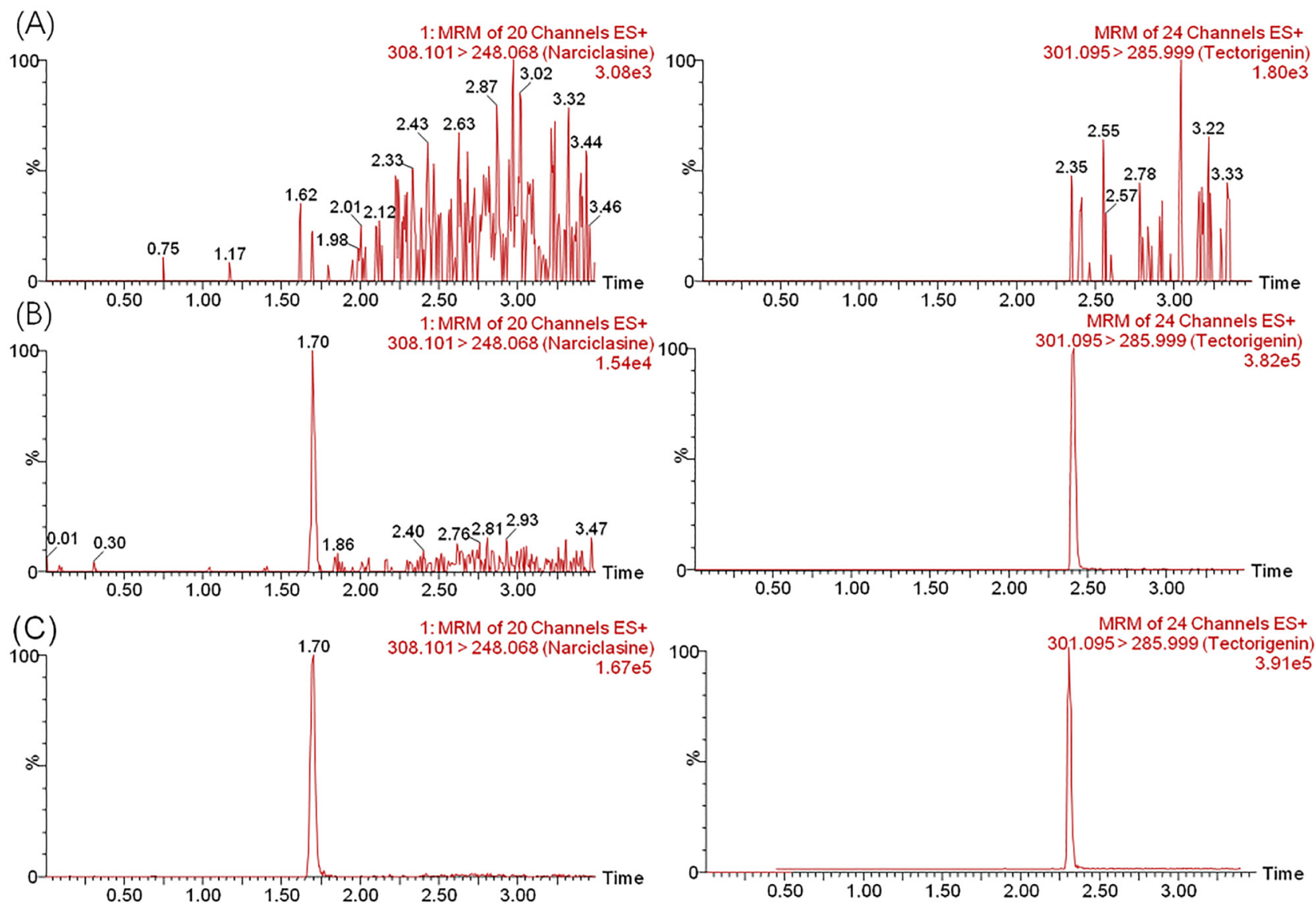

Fig. 2. Narciclasine and IS chromatograms obtained by UPLC/MS/MS in mouse blood. (A) a blank blood sample, (B) the blank blood samples spiked with narciclasine $(1 \mathrm{ng} / \mathrm{mL})$ and $\mathrm{IS},(\mathrm{C})$ a blood samples after intravenous administration 
Table 1. The accuracy, precision, matrix effect and recovery of narciclasine in mouse blood samples $(n=6)$

\begin{tabular}{|c|c|c|c|c|c|c|}
\hline \multirow[b]{2}{*}{ Concentration $(\mathrm{ng} / \mathrm{mL})$} & \multicolumn{2}{|c|}{ Precision (\%) } & \multicolumn{2}{|c|}{ Accuracy (RSD\%) } & \multirow[b]{2}{*}{ Metrix effect (\%) } & \multirow[b]{2}{*}{ Recovery (\%) } \\
\hline & Intra-day & Inter-day & Intra-day & Inter-day & & \\
\hline 1 & 10.5 & 13.6 & 92.5 & 107.3 & 104.7 & 70.8 \\
\hline 2 & 3.4 & 6.9 & 101.8 & 99.4 & 106.6 & 67.4 \\
\hline 450 & 4.5 & 7.3 & 105.2 & 103.9 & 107.4 & 66.2 \\
\hline 5,000 & 8.4 & 2.7 & 101.0 & 97.1 & 103.6 & 65.7 \\
\hline
\end{tabular}

Table 2. Main Pharmacokinetic study of narciclasine after intravenous administration

\begin{tabular}{lcc}
\hline Parameters & Unit & iv $(5 \mathrm{mg} / \mathrm{kg})$ \\
\hline $\mathrm{AUC}_{(0-\mathrm{t})}$ & $\mathrm{ng} / \mathrm{mL} \times \mathrm{h}$ & $2448.1 \pm 408.6$ \\
$\mathrm{AUC}_{(0-\infty)}$ & $\mathrm{ng} / \mathrm{mL} \times \mathrm{h}$ & $2452.5 \pm 408.7$ \\
$\mathrm{MRT}_{(0-\mathrm{t})}$ & $\mathrm{H}$ & $0.8 \pm 0.2$ \\
$\mathrm{MRT}_{(0-\infty)}$ & $\mathrm{H}$ & $0.9 \pm 0.2$ \\
$\mathrm{t}_{1 / 2 \mathrm{z}}$ & $\mathrm{H}$ & $1.7 \pm 0.2$ \\
$\mathrm{CL}_{\mathrm{z} / \mathrm{F}}$ & $\mathrm{L} / \mathrm{kg}$ & $2.1 \pm 0.3$ \\
$\mathrm{~V}_{\mathrm{z} / \mathrm{F}}$ & $\mathrm{L} / \mathrm{h} / \mathrm{kg}$ & $5.2 \pm 1.3$ \\
$\mathrm{C}_{\max }$ & $\mathrm{ng} / \mathrm{mL}$ & $4452.9 \pm 996.5$ \\
\hline
\end{tabular}

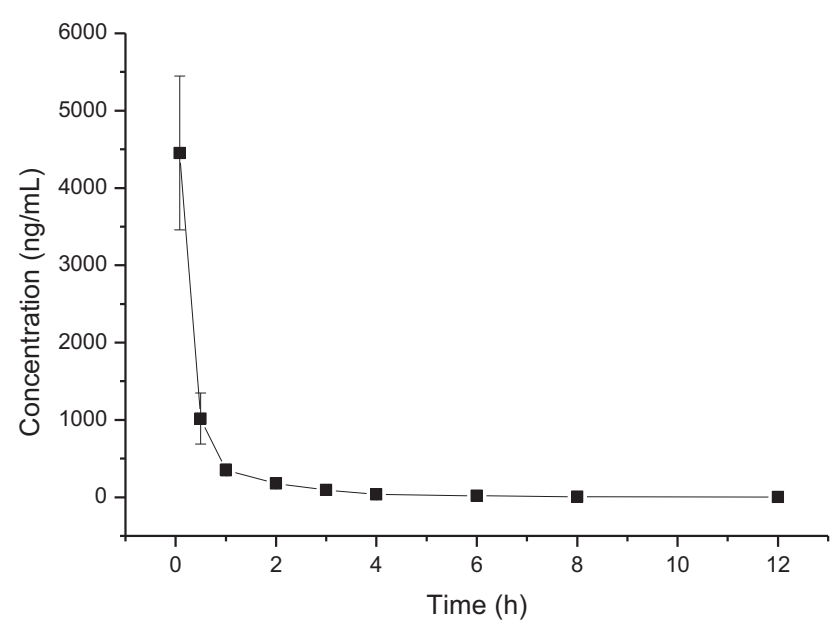

Fig. 3. Mean plasma concentration-time profile after intravenous administration of narciclasine $(5 \mathrm{mg} / \mathrm{kg})$

\section{Pharmacokinetic study}

The main pharmacokinetic parameters of narciclasine were fiited by the non-compartment model, Table 2. The blood concentration of narciclasine was showed in Fig. 3.

\section{DISCUSSION}

We chose the positive mode for the response of the narciclasine was stronger than that in the negative ion mode. Then fragment peaks with relatively high fragments were selected as quantitative ion pairs, $m / z 308.1 \rightarrow 248.1$ for narciclasine (cone voltage $12 \mathrm{v}$, collision voltage $18 \mathrm{v}$ ) and $\mathrm{m} / \mathrm{z}$ $301.1 \rightarrow 286.0$ for IS (cone voltage $52 \mathrm{v}$, collision voltage 26 v), were shown in Fig. 1.
The different mobile phase was tested, such as acetonitrile, $0.1 \%$ formic acid in water, $10 \mathrm{mmol} / \mathrm{L}$ ammonium acetate and methanol. The methanol and $0.1 \%$ formic acid in water was used as the mobile phase, it achieved the suitable retention time $(1.7 \mathrm{~min})$ and better peak.

Choosing sample treatment method was very important in methodology [17-21]. The extraction efficiencies of ethyl acetate, acetonitrile, and methanol were compared. The extraction efficiencies of acetonitrile (around 70\%) were better than ethyl acetate (around 50\%) and methanol (around 50\%). And the matrix effects of acetonitrile were acceptable (around 105\%).

To select the internal standard during the method establishment process was very important [22-26]. Several compounds including astragalin, tectorigenin, rubiadin and narciclasine were compared. It was comprehensively shown that tectorigenin had a structure, and the peak time was similar to that of narciclasine.

UPLC-MS/MS was applied to the quantitative analysis of narciclasine in mouse blood, which was much faster than traditional HPLC (retention time of narciclasine was 5.0 $\mathrm{min})$, and needed less blood $(20 \mu \mathrm{L})$ [16]. No literature has been reported on the pharmacokinetics of narciclasine in rats or mice.

\section{CONCLUSIONS}

A simple UPLC-MS/MS method was developed for determination of narciclasine in mouse with the LLOQ of $1 \mathrm{ng} /$ $\mathrm{mL}$. The developed UPLC-MS/MS method was successfully applied to the pharmacokinetics in mice.

\section{ACKNOWLEDGMENTS}

This work was supported by Wenzhou science and Technology Bureau (Y2020882), the second batch of agricultural cooperatives in Yinzhou District in 2018 (NO. 23).

\section{REFERENCE}

1. Ding, Y.; Qu, D.; Zhang, K. M.; Cang, X. X.; Kou, Z. N.; Xiao, W.; Zhu, J. B. J. Asian Nat. Prod. Res. 2017, 19, 53-100.

2. Nair, J. J.; Bastida, J.; Codina, C.; Viladomat, F.; van Staden, J. Nat. Prod. Commun. 2013, 8, 1335-50. 
3. N'Tamon, A. D.; Okpekon, A. T.; Bony, N. F.; Bernadat, G.; Gallard, J. F.; Kouame, T., Seon-Meniel, B., Leblanc, K., Rharrabti, S., Mouray, E., Grellier, P., Ake, M., Amin, N. C., Champy, P., Beniddir, M. A.; Le Pogam, P. Phytochemistry 2020, 179, 112485.

4. Gasca, C. A.; Moreira, N. C. S.; de Almeida, F. C.; Dutra-Gomes, J. V.; Castillo, W. O.; Fagg, C. W.; Magalhaes, P. O.; Fonseca-Bazzo, Y. M.; Sakamoto-Hojo, E., de Medeiros, Y. K., de Souza Borges, W.; Silveira, D. Food Chem. Toxicol. 2020, 111703.

5. Sibanyoni, M. N.; Chaudhary, S. K.; Chen, W.; Adhami, H. R.; Combrinck, S.; Maharaj, V.; Schuster, D.; Viljoen, A. Fitoterapia 2020, 146, 104650.

6. Koutova, D.; Maafi, N.; Havelek, R.; Opletal, L.; Blunden, G.; Rezacova, M.; Cahlikova, L. Molecules 2020, 25, 2337.

7. Trujillo-Chacon, L. M.; Alarcon-Enos, J. E.; Cespedes-Acuna, C. L.; Bustamante, L.; Baeza, M.; Lopez, M. G.; Fernandez-Mendivil, C.; Cabezas, F.; Pastene-Navarrete, E. R. Food Chem. Toxicol. 2019, 132, 110665.

8. Cole, E. R.; de Andrade, J. P.; Filho, J. F. A.; Schmitt, E. F. P.; Alves-Araujo, A.; Bastida, J.; Endringer, D. C.; de, S. B. W.; Lacerda, V. Anticancer Agents Med. Chem. 2019, 19, 707-17.

9. Nair, J. J.; Bastida, J.; van Staden, J. Nat. Prod. Commun. 2016, 11, 121-32.

10. Isbilen, O.; Rizaner, N.; Volkan, E. BMC Complement. Altern. Med. 2018, 18, 30.

11. Chen, M. X.; Huo, J. M.; Hu, J.; Xu, Z. P.; Zhang, X. Fitoterapia 2018, 130, 48-53.

12. Gopalakrishnan, R.; Matta, H.; Choi, S.; Chaudhary, P. M. Sci. Rep. 2020, 10, 5712 .
13. Brautigam, J.; Bischoff, I.; Schurmann, C.; Buchmann, G.; Epah, J.; Fuchs, S.; Heiss, E.; Brandes, R. P.; Furst, R. J. Mol. Cel Cardiol. 2019, 135, 97-108.

14. Zhang, X.; Xiang, Q.; Zhao, X.; Ma, L.; Cui, Y. J. Clin. Pharm. Ther. 2019, 44, 163-73.

15. Millar, S. A.; Stone, N. L.; Yates, A. S.; O'Sullivan, S. E. Front. Pharmacol. 2018, 9, 1365.

16. Svagrova, I.; Stulik, K.; Pacakova, V.; Caliceti, P.; Veronese, F. M. J. Chromatogr. 1991, 563, 95-102.

17. Qiu, E. J.; Wang, H. Z.; Yu, Y.; Song, D. Z.; Cai, J. Z.; Ye, F. F. Latin Am. J. Pharm. 2020, 39, 1171-5.

18. Liu, Z. Z.; Liu, H. M.; Wu, Y. Z.; Xu, X. X.; Ma, J. S. Latin Am. J. Pharm. 2020, 39, 1116-21.

19. Chen, S. J.; Zhou, C. P.; Hu, Y. J.; Wang, H. Z.; Liu, F. L. Latin Am. J. Pharm. 2020, 39, 208-12.

20. Ye, W. J.; Lin, C. L.; Lin, G. Y.; Chen, R. J.; Sun, W.; Wang, S. H.; Wang, X. Q.; Zhou, Y. F. Curr. Pharm. Anal. 2019, 15, 604-11.

21. Song, H. C.; Huang, Y. W.; Zhu, D. Q.; Tong, S. H.; Zhang, M. L.; Wang, X. Q.; Bao, X. Curr. Pharm. Anal. 2019, 15, 194-9.

22. Li, T. R.; Ye, W. J.; Huang, B. G.; Lu, X. J.; Chen, X. X.; Lin, Y. J.; Wen, C. C.; Wang, X. Q. J. Pharm. Biomed. Anal. 2019, 168, 133-7.

23. Ren, K.; Jin, Y.; Wang, X. Q.; Wei, Z. Latin Am. J. Pharm. 2019, 38, 991-5.

24. Chen, L. G.; Yang, J. Y.; Chen, D. W.; Xiong, J. H.; Wang, X. Q.; Ying, X. Q.; Wei, Y. L.; Lin, Y. P.; Zhang, S. Z.; Wu, M. L. Latin Am. J. Pharm. 2019, 38, 855-9.

25. Chen, J. F.; Bao, X.; Lin, C. L.; Zhou, G. E. Latin Am. J. Pharm. 2019, 38, 985-90.

26. Chen, L. G.; Weng, Q. H.; Lin, Y. J.; Lu, X. J.; Zhong, Z. Q., Xiong, J. H.; Wang, X. Q. Curr. Pharm. Anal. 2020, 16, 705-11. 